\title{
KNX system - energy saving not only in the sphere of lighting
}

\begin{abstract}
System of electrical installations KNX would be possible to cover up to whole number of different systems, which are determined to control less or most number of functions intended to good internal conditions of buildings are needed. But KNX system is only one standardized system in the world and therefore also the most extended system. The reason of it is in its specialization to control of all functions, which are needed to ensure the best internal conditions for people, not only in small, but in the biggest buildings too. KNX system cooperate without any problems with many other partial systems specialized to regulation of special function parts e.g. air-conditioning, ventilation etc. Because KNX is an open system, it cooperates with the other open systems, and there is possible to reach minimally energy consumption in whole building, but there is not influenced the comfort in all rooms of building. The consumption of all types of energy in every room is only according to instantaneous conditions required with persons. If is nobody there, the consumption is automatically limited. The result of cooperation of all components of KNX installation is energy saving in the range between of $30 \%$ to $60 \%$, depending of level of supply with KNX.
\end{abstract}

Keywords: system KNX, system of electrical installation, energy saving.

\section{Úvod}

Funkce ovládané systémovou KNX elektrickou instalaci zajistí v budovách na jedné straně vysoký komfort při řízen funkcí, na straně druhé je možné vzájemně provázat řízení všech těchto funkcí tak, aby nedocházelo prakticky k žádnému plýtvání energií. Konečně, mnozí z nás zaznamenali vysoké plýtvání tepelnou energií v prostorech vybavených na sobě nezávislými systémy vytápění a klimatizace. Není zde totiž nic až tak mimořádného, že oba systémy jsou současně $v$ provozu. Přitom pro zajištěni potřebného vnitřního klimatu by $v$ dané chvíli postačilo, aby oba byly $v$ naprosté nečinnosti.

Při použití KNX systémové instalace Ize dosáhnout skutečně až nečekaně vysokých úspor provozních nákladů především ve srovnání s instalací klasickou. Je tomu tak proto, že i při použití sice dokonalých, avšak pouze na jednu funkční oblast specializovaných řídicích systémů, často dochází ke zbytečné spotřebě energie. Bude tomu tak především $v$ právě nepoužívaných prostorách anebo $v$ místnostech sice používaných, ale třeba nadměrně zahřívaných prímým slunečním svitem.

\section{Jak vznikal KNX systém}

$S$ rozvojem vědy a techniky se ve světě vyskytovaly snahy o využití nejnovějších vědeckých poznatků pro zvýšení pohodlí, pro zjednodušení rưzných pracovních činností, pro zvýšení produktivity práce a v neposlední řadě také pro co nejefektivnější využití energie. Již od počátků elektrifikace se elektřina prosazovala pro osvětlování, pro využití v různých technologických procesech. Nejdřive zcela izolovaně pro manuálně ovládané jednotlivé okruhy osvětlování a individuálně spínané spotřebiče bez jakýchkoliv možných vzájemných vazeb. Proto jakákoliv optimalizace spotřeby energie, spojená s nutností ji regulovat, závisela pouze na lidském činiteli, tedy na ruční regulaci.

$\mathrm{V}$ polovině 60 . let minulého století byl $\mathrm{v}$ Japonsku uskutečněn pokus se zajištěním komplexní regulace spotřeby tepla a řízení osvětlení v rodinném domě využitím samočinného počítače. Uvědomme si, že relativně málo výkonný a energeticky vysoce náročný počítač byl v tehdejší době představován souborem několika skřín vybavených elektronickými obvody z diskrétních součástek, $\mathrm{s}$ nutností umístění v klimatizované místnosti. Navíc, jeho cena zajisté značně převyšovala cenu celého rodinného domu i s použitými technickými a technologickými celky. Nebylo tedy možné počitat s praktickým využitím takto navrženého systému - tzn. systému s centrálním počítačem.
Podstatou tohoto úspěšného technického pokusu bylo pouze potvrzení domněnek, že moderní výpočetní technikou bude možné ovládat i funkce $v$ domech a bytech, včetně možností jejich vzájemné interakce.

Je nutné poznamenat, že tehdy neexistovaly žádné ekonomické tlaky na úspory energie. Uvážíme-li navíc, že na světovém trhu se prodával jeden barel ropy za pouhých 50 centů. Šetřit energií bylo tehdy neekonomické.

$\checkmark$ první polovině 70 . let 20 . století došlo k zásadnímu obratu. Výsledkem tehdejší energetické krize bylo výrazné zvýšení ceny ropy. To znamenalo, že energie již nebyla téměř zdarma, ale naopak bylo potřebné zabývat se snižováním energetické náročnosti budov.

Proto se urychlovalo dokončení dřive rozpracovaných vývojových programů zaměřených na snižení energetické náročnosti. $\mathrm{V}$ polovině 70 . let byly již $\mathrm{k}$ dispozici sice ještě poměrně drahé, ale ve srovnání se sálovými počítači výrazně levnější a energeticky mnohem méně náročné osobní počitače, nevyžadující umístění v klimatizovaných prostorách, a které bylo možné efektivně využívat pro rízení některých funkcí v budovách.

Další miniaturizace elektronických součástek dovolila vytvářet programovatelné př́stroje určené pro montáž do rozvaděčů i do elektroinstalačních krabic. Každý z těchto přístrojů potom mohl mít naprogramovány dílčí činnosti a způsob komunikace s dalšími přístroji. Takto nejdřive byly vytvářeny systémy s centrálními řídicími jednotkami, později i decentralizované.

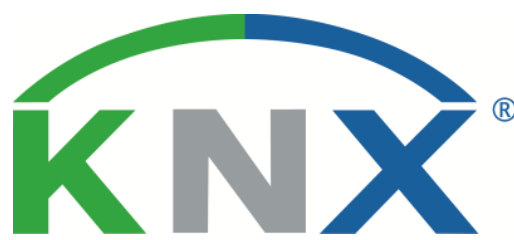

Obr. 1: Logo Mezinárodní asociace KNX

$\checkmark$ roce 1987 ve spolupráci několika firem vznikla asociace Instabus ${ }^{\circledR}$. Jejím účelem bylo vytvořit takový systém, který umožní použití programovatelných přístrojů různých výrobců ve společné systémové instalaci.

$\mathrm{Na}$ práci této asociace navázala v roce 1989 vzniklá asociace EIBA (European Installation Bus Association Asociace pro evropskou instalační sběrnici). Nakonec v roce 1999 dochází ke sloučení asociace EIBA se dvěma dalšími evropskými odbornými seskupeními (Batibus a EHSA) do nového sdružení - asociace KNX. 
Mezinárodní asociace KNX plně navázala na činnost predchozí asociace EIBA. Znamená to tedy, že systémy EIB i KNX jsou shodné, jejich komponenty jsou vyráběny podle shodných norem. Všechny přístroje, bez ohledu na výrobce, musí být schopny vzájemně komunikovat a spolupracovat při řízení funkcí [1].

\section{Co umí systém KNX}

Zjednodušeně Ize říci - systém umí všechno, co je potřebné pro zajištění správné činnosti osvětlení, stínicích prostředků, vnitřního klimatu, zabezpečení objektu, měření, hlášení pracovních či poruchových stavů, vizualizace a mnohých dalších funkcí.

Jaké funkce umí tato instalace rí́dit, to závisí na jejím přístrojovém vybavení. Ovšem mnohem podstatnější vlastností je možnost vzájemného provázání řízení jednotlivých funkcí takové, aby jejich ovládání bylo co nejjednodušší, aby se vzájemně podporovaly s cílem dosažení co nejmenší energetické náročnosti budovy, pritom však bez jakéhokoli omezení komfortu a pracovních či životních podmínek přitomných osob.

Decentralizovaný, stavebnicový systém KNX je určen pro účelné využití v objektech jakékoli velikosti. Čím vyšším počtem různých funkcí je objekt vybaven, tím výhodnějši bude využití KNX. Pro plně porovnatelný způsob ovládání funkcí v klasické a systémové KNX instalaci je potřebné danou instalaci vybavit potřebnými přístroji nejen pro jejich samostatné ovládání, ale i pro zajištění jejich součinnosti. Vzhledem k tomu, že vzájemná spolupráce funkcí je v systémové instalaci zajištována ponejvíce softwarovými vazbami, zatímco $v$ klasických instalacích je $\mathrm{k}$ tomuto účelu zcela nezbytné vybavení hardwarové, můžeme poměrně snadno dospět $\mathrm{k}$ závěru, ověřenému praxí: Čím vyšší počet dílčích funkcí je vobjektu využíván, tím je ekonomicky výhodnější použití KNX systémové instalace, jak je graficky znázorněno na obr. 2.

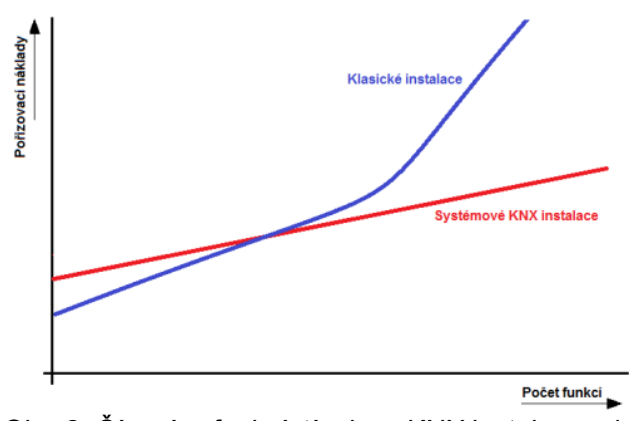

Obr. 2: Čím více funkcí, tím jsou KNX instalace relativně levnější

Základní výhodou KNX instalace je možnost komplexního individuálního řizení jednotlivých místností, nezávisle na ostatních prostorách. To si můžeme ukázat např. na řízení osvětlení.

\section{Řizení osvětlení a dalších funkcí v KNX systému}

Řízení osvětlení patří k funkčním oblastem, bez nichž se neobejde žádná budova. Bude-li $v$ budově požadováno pouze spínání osvětlení, pořizovací náklady na ovládací prvky budou nižší v klasické instalaci, než v instalaci KNX. Ovšem na druhou stranu je nutné poznamenat, že jen výjimečně se vyskytují objekty, v nichž je pro systémovou instalaci požadováno jen prosté spínání osvětlení.

Ke spínání osvětlení v KNX systémových instalacích přistupuje řada dalších funkcí, jakými jsou:

- Stmívání osvětlení

- Rízení na stálou osvětlenost

- Vazba provozu osvětlení na prítomnost osob

- Centrální funkce
Předem nastavené hodnoty intenzity osvětlení pro různé účely (pro běžný provoz, pro úklid, pro strážní službu)

\section{Scénický provoz}

Logické vazby

Časově zpožděné samočinné vypnutí

Zablokování v předem určeném stavu

Vazba na určité měřené hodnoty

Odesílání aktuálních hodnot

Nejen zmíněné, ale i mnohé další funkce Ize realizovat při použití současných KNX přístrojů jejich vhodným naprogramováním. $K$ nastavení jejich součinnost $s$ dalšími prvky v KNX systémové instalaci obvykle nejsou potřebné přídavné komponenty, vystačí využít možností aplikačních programů již nainstalovaných př́istrojů.

Především v komerčních a podobných objektech, v nichž se ovládá osvětlení s vysokými počty svítidel, je výhodná spolupráce dvou typů sběrnic. Svítidla vybavená digitálními adresovatelnými předřadníky připojená ke sběrnici DALI (Digital Addressable Lighting Interface), zatímco ovladače jsou součástí sběrnice KNX. Obě sběrnice jsou vzájemně provázány KNX/DALI rozhraním. Ke každé DALI sběrnici lze připojit až 64 DALI předřadníků. Je možné naprogramovat individuální, skupinové i centrální ovládání svítidel. DALI předřadníky jsou koncipovány nejen pro spínání, ale i pro stmívání. Na obr. 3 je př́iklad použití jednoho $z$ typů KNX/DALI rozhraní, $k$ němuž Ize připojit až osm na sobě nezávislých skupin svítidel řízených na stálou osvětlenost.

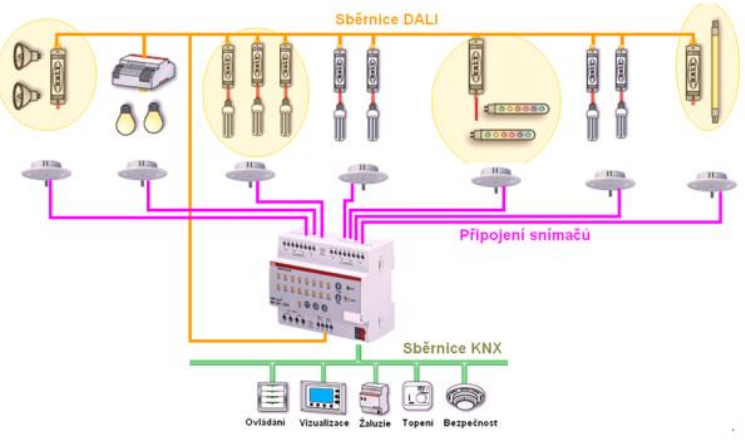

Obr. 3: Energeticky úsporné řízení svítidel na stálou osvětlenost spoluprací sběrnic KNX a DALI [2]

Řízení na stálou osvětlenost v kancelářských a podobných objektech je zdrojem významných úspor energie na osvětlování. Ještě vyšší úspory energie zajistí vazba na prítomnost osob $v$ takto osvětlovaných prostorách. A inned se nabízí vazby na rízení dalších funkcí, především na vytápění a chlazení. Dosud byl režim řízení teploty navázán pouze na časové programy. Ovšem ty nemohou snadno postihnout fakt, že až $30 \%$ časově řízených místností zůstává prázdných. A v nich je zbytečně udržována teplota na úrovni vytvořené pro př́ijemné pracovní prostředí, príčemž by plně postačilo teplotu udržovat na pohotovostní hodnotě, tedy s nižší energetickou náročností. V KNX instalaci se proto podle časového programu přepínaji individuálně nastavené termostaty pouze mezi úsporným a pohotovostním režimem, přepnutí do komfortního režimu provozu zajištuje vazba na prítomnost. Potom Ize např. na vytápění ušetřit nejméně dalších $8 \% \mathrm{z}$ provozních nákladů.

Kancelářské a podobné místnosti bývají běžně vybavovány i stínicími prostředky - především venkovními žaluziemi pro zabezpečení osob před oslněním přímým slunečním světlem. Potom je ale potřebné, aby žaluzie byly řízeny zcela automaticky - lamely se samočinně natáčejí a do vnitřního prostoru směrují co nejvíce přirozeného světla, 
ovšem bez oslňování, přičemž současně odrážejí tepelné záření dovnitř (při spolupráci s topením - úspora energie na vytápění až $15 \%$ ) nebo do venkovního prostoru (při spolupráci s chlazením - úspora energie na chlazení až $30 \%)$.

Při řízení venkovních žaluzií, ale také markýz, střešních oken apod. je důležité svázat činnost těchto zařízení s okamžitými povětrnostními podmínkami, aby nedošlo k jejich poškození silným větrem, namrzajícím deštěm a současně pro zabránění prípadným škodám na majetku vzniklých do objektu vnikajícím deštěm apod. K tomu jsou mj. potřebné povětrnostní stanice. Ty svými snímači (příklad na obr. 4) sledují okamžité povětrnostní podmínky a předávají potřebné informace na sběrnici. Začne-li např. foukat silnější vítr, než je stanovená mez pro venkovní žaluzii nebo markýzu, tento stínicí prostředek se svine do zabezpečené polohy a $v$ ní zůstane zablokován, pokud trvá větrný poplach.

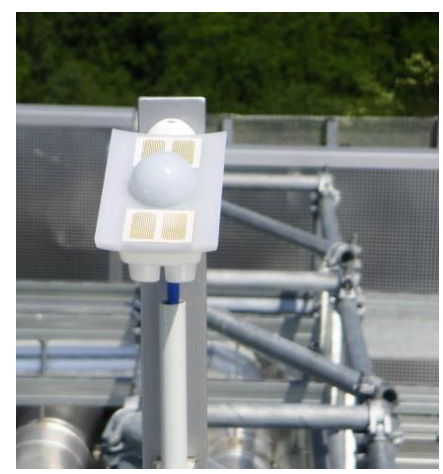

Obr. 4: Kombinovaný snímač povětrnostních údajů předává měřená data KNX systému pro další zpracování

Je-li budova vybavena dvojitým pláštěm a žaluzie jsou namontovány $v$ takto vzniklém prostoru mezi fasádami (obr. 5), prostředky stínění jsou chráněny před přímými účinky nepřiznivých povětrnostních vlivů (vítr, déšt', mráz). Tyto klimatické vlivy není potom zapotřebí uvažovat $v$ průběhu provozu takto umístěných žaluzií. Kromě toho, žaluzie mohou být lehčí konstrukce, než by musely být při montáži na vnější fasádu.

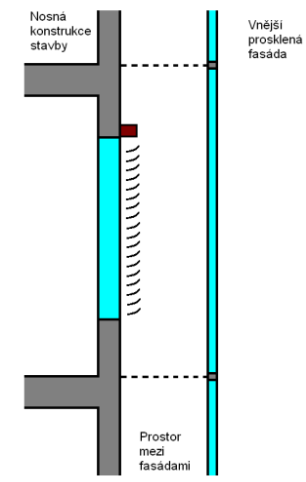

Obr. 5: Žaluzie namontovaná v prostoru mezi nosnou konstrukcí a vnější fasádou

V prostoru mezi oběma fasádami se ovšem hromadí odpadní teplo. To může být bez užitku vypouštěno do venkovního prostoru, anebo lépe, použito např. pro ohřev užitkové vody, čímž se dále zvýší energetická efektivita budovy.

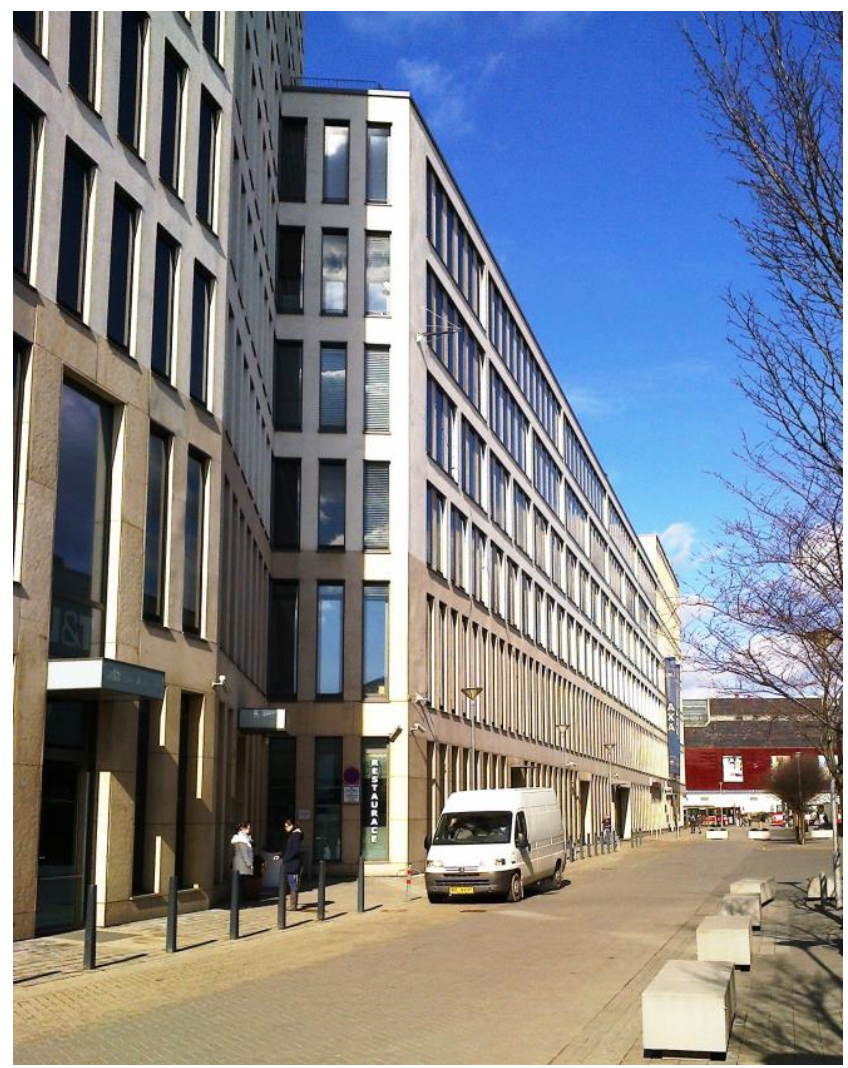

Obr. 6: Budova s dvojitým pláštěm

V nejjednodušším případě jsou žaluzie ovládány manuálně (tlačítkovými ovladači, dotykovými panely apod.), samozřejmě s blokováním provozu při silném větru, mrznoucím dešti apod. Pro automatický provoz je ale nezbytné instalaci doplnit o logický modul specializovaný na rízení stínicí techniky ve spolupráci s údaji o povětrnostních podmínkách (obr. 7), obsahující i data týkající se okamžité vzájemné polohy Slunce a budovy. Potom budou zastíněna pouze osluněná okna, žaluzie na ostatních oknech budou svinuty, aby vůbec nebránily prístupu denního světla do místností (obr. 8).

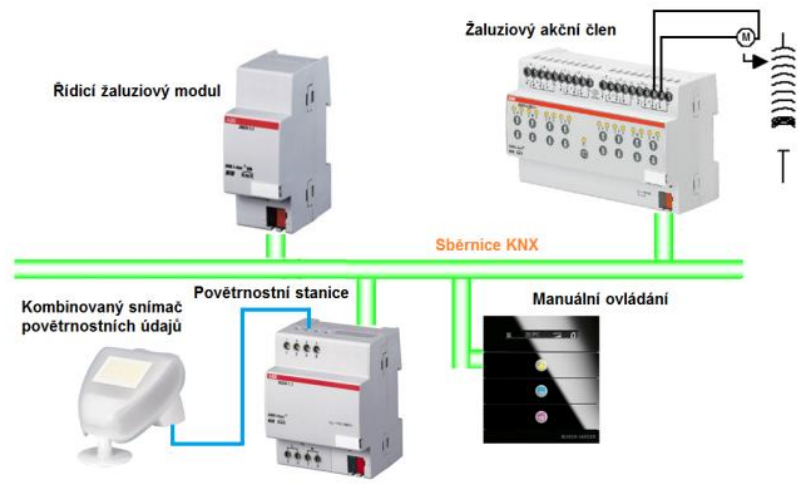

Obr. 7: Schematické znázornění řizení provozu žaluzií

V KNX instalacích je poměrně snadné naprogramovat libovolně složité vazby pro řízení všech funkcí a do regulačních procesů zahrnout veškeré fyzikální veličiny, které mohou mít dopad na spotřebu energie $v$ budově. Jen je nezbytné umět správně definovat požadavky. Teprve podle toho je projektant schopen správně navrhnout celé řešení KNX instalace. 


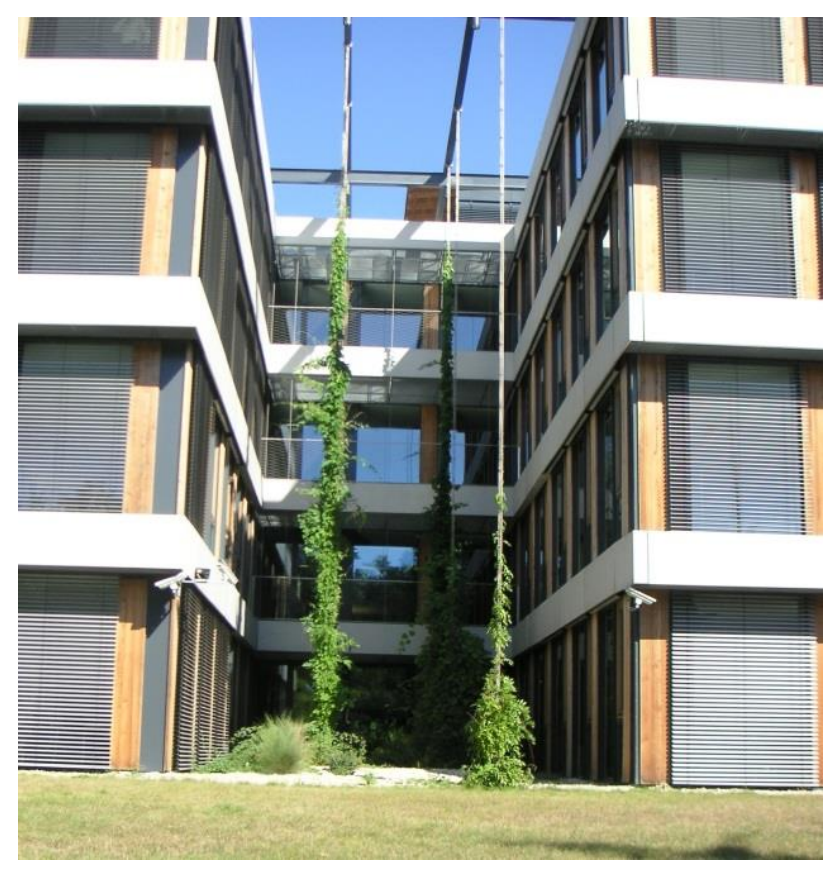

Obr. 8: Na zastíněných oknech jsou žaluzie svinuty

\section{Využití KNX v České republice}

Mezi projektanty bychom asi jen obtížně našli takového, který by se ve své profesní praxi alespoň jedenkrát nesetkal s KNX systémovou instalací. Přitom celá řada $z$ nich již aktivně pracuje $s$ touto soustavou. Důležitým motivem pro stále širší nasazení KNX instalací v projektech nových budov nebo také v rozsáhlých rekonstrukcích je fakt, že se jedná o jedinou mezinárodně normalizovanou inteligentn soustavu, vytvořenou pro řízení všech funkcí používaných v budovách. Dalším významným faktorem je možnost výběru potřebných přístrojů od více než 360 výrobců ze všech kontinentů, což je oceňováno jako obrovská výhoda - není potřebné vázat se pouze na prístroje a systém jednoho výrobce, navíc ve značné většině prípadů s omezenou funkcionalitou.

Pro stále vyšší počet zájemců o práci s KNX systémem jsou určena školicí centra, $v$ nichž se účastníci školení mohou seznámit $s$ podstatou systému a s principiálně velmi jednoduchým způsobem práce s ním.

Ovšem pouhá činnost školicích center není plně postačující pro další šíření potřebných informací o KNX systémové instalaci. $\mathrm{V}$ mnoha zemích napomáhají národní skupiny KNX při koordinaci celé řady podpưrných akcí. To se potom projevuje $v$ mnohem širším využívání KNX systému $v$ instalacích a také širokému povědomí o něm nejen $v$ odborných elektrotechnických kruzích, ale i mezi architekty a investory.

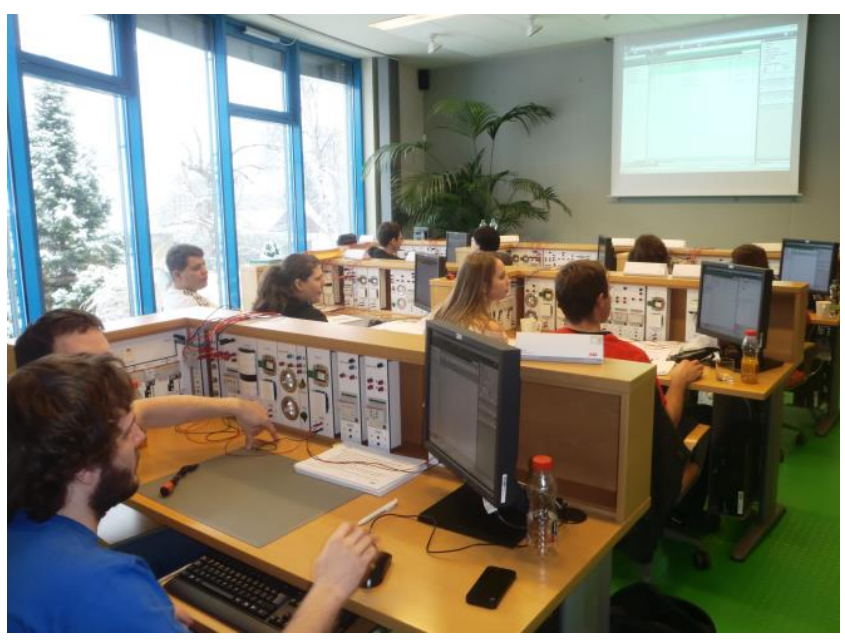

Obr. 9: Praktická cvičení ve školicím centru

Donedávna takováto organizace $v$ naší republice chyběla. Avšak v letošním roce se za účasti zástupců výrobců KNX přístrojů, systémových integrátorů a vysokých škol podařilo obdobnou společnost založit také u nás. Prostory pro její činnost poskytuje VUT Brno, fakulta elektrotechniky a komunikačních technologií a je registrovaná jako Spolek KNX národní skupina České republiky.

Tento spolek začal vyvijet aktivity zaměřené na další rozšiřování znalostí o KNX systémových instalací v ČR na různých technických konferencích, výstavních akcích, ale také publikováním v odborném tisku, pořádáním workshopů pro architekty, projektanty a investory a také prohlubováním spolupráce se středními i vysokými technickými školami. Je totiž důležité, aby již absolventi těchto škol, ještě před príchodem do praxe, získali základní teoretické i praktické znalosti o KNX systémových instalacích.

\section{PODKLADY}

[1] Informativní materiály Mezinárodní asociace KNX www.knx.org

[2] Školicí podklady KNX

[3] Archiv autora

Autor: Ing. Josef Kunc, KNX národní skupina České republiky, VUT FEKT Brno, Technická 10, Czech Republic, e-mail: eibsyst@volny.cz 